\title{
KONTRIBUSI PRAKTIK KERJA INDUSTRI (PRAKERIN), DISIPLIN BELAJAR, MOTIVASI BERPRESTASI, DAN KOMPETENSI PEDAGOGIK GURU TERHADAP HASIL BELAJAR TATA GRAHA SISWA KELAS XII JURUSAN PERHOTELAN DI SMK NEGERI 2 SINGARAJA
}

\author{
Luh Suardani, I Nyoman Natajaya, I Gusti Ketut Arya Sunu \\ Program Studi Administrasi Pendidikan, Program Pascasarjana \\ Universitas Pendidikan Ganesha \\ Singaraja, Indonesia
}

e-mail: \{luh.suardani, nyoman.natajaya, arya.sunu\}@pasca.undiksha.ac.id,

\begin{abstract}
Abstrak
Penelitian ini bertujuan untuk mengetahui kontribusi praktik kerja industri (prakerin), disiplin belajar, motivasi berprestasi, dan kompetensi pedagogik guru terhadap hasil belajar Tata Graha. Penelitian ini adalah penelitian "ex-post facto" dengan besar sampel 113 orang. Data dikumpulkan dengan kuesioner dan dokumen. Analisis data dilakukan dengan teknik regresi sederhana, regresi ganda, dan korelasi parsial. Hasil penelitian menunjukkan bahwa: 1) terdapat kontribusi yang signifikan prakerin terhadap hasil belajar Tata Graha dengan koefisien korelasi sebesar 0,605, korelasi parsial sebesar 0,272 dan sumbangan efektifnya sebesar $13,18 \%$. 2) terdapat kontribusi yang signifikan disiplin belajar terhadap hasil belajar Tata Graha dengan koefisien korelasi sebesar 0,734, korelasi parsial sebesar 0,225 dan sumbangan efektifnya sebesar $20,44 \%$. 3) ada kontriubusi yang signifikan motivasi berprestasi terhadap hasil belajar Tata Graha dengan koefisien korelasi sebesar 0,486, korelasi parsial sebesar 0,229 dan sumbangan efektifnya sebesar $7,89 \%$. 4) terdapat kontribusi yang signifikan kompetensi pedagogik terhadap hasil belajar Tata Graha dengan koefisien korelasi sebesar 0,733 , korelasi parsial sebesar 0,241 dan sumbangan efektifnya sebesar 21,66\%. 5) secara bersama-sama, terdapat kontribusi yang signifikan prakerin, disiplin belajar, motivasi berprestasi, dan kompetensi pedagogik terhadap hasil belajar Tata Graha pada siswa kelas XII Jurusan Perhotelan di SMK Negeri 2 Singaraja dengan koefisien korelasi ganda sebesar 0,794 dan kontribusinya sebesar $63,10 \%$ terhadap hasil belajar Tata Graha siswa kelas XII Jurusan Perhotelan di SMK Negeri 2 Singaraja.
\end{abstract}

Kata kunci: praktik kerja industri, disiplin belajar, motivasi berprestasi, kompetensi pedagogik, hasil belajar Tata Graha

\begin{abstract}
This study aims to determine the contribution of industrial work practices (prakerin), discipline of learning, achievement motivation, and pedagogical competence of teachers to the results learning of Tata Graha. This study is an "ex-post facto" study with a sample size of 113 people. Data were collected with questionnaires and documents. Data analysis was performed by simple regression, multiple regression, and partial correlation. The result of the research shows that: 1) there is a significant contribution prakerin to the learning result of Tata Graha with correlation coefficient of 0.605 , partial correlation of 0,272 and effective contribution of $13.18 \%$. 2) there is a significant contribution the learning discipline of the learning result of Tata Graha with a correlation coefficient of 0.734 , partial correlation of 0,225 and effective contribution of $20.44 \%$. 3) there is significant contriubution achievement motivation toward learning result of Tata Graha with correlation coefficient 0,486 , partial correlation of 0,229 and effective contribution equal to $7,89 \%$. 4) there is significant contriubution pedagogic competence on the learning result of Tata Graha with correlation coefficient of 0,733 , partial correlation of 0,241 and effective contribution equal to $21,66 \%$. 5) collectively, there is a significant contribution prakerin, learning discipline, achievement motivation, and pedagogic competence on the learning result of Tata Graha in grade XII students Department of Hospitality in SMK Negeri 2 Singaraja with double correlation coefficient of 0.794 and its contribution is $63,10 \%$ of the learning result of Grade Students of Grade XII Department of Hospitality at SMK Negeri 2 Singaraja.
\end{abstract}

Keywords: industrial work practices, learning discipline, achievement motivation, pedagogic competence, learning outcomes of Tata Graha 


\section{PENDAHULUAN}

Sekolah Menengah Kejuruan (SMK) adalah salah satu komponen yang patut dikembangkan dalam pendidikan di Indonesia. Di era perdagangan bebas Masyarakat Ekonomi Asean (MEA), tuntutan kebutuhan sumber daya manusia (SDM) yang terampil di bidangnya mutlak diperlukan. Indonesia sebagai pemasok tenaga kerja yang cukup produktif di mata internasional, harus bersaing dengan negara lain yang sistem pendidikannya beberapa diantaranya lebih maju dari Indonesia sehingga mampu menghasilkan angkatan kerja yang mumpuni di bidangnya. Untuk memenuhinya, kesiapan kualitas SDM angkatan kerja harus makin ditingkatkan. Jalurnya perlu dipersiapkan melalui sistem pendidikan yang disesuaikan untuk mampu mengatasi kebutuhan sumber daya manusia yang siap kerja (Ramelan, Iskandar, dan Handayani, 2009:36).

Sejak ekonomi Indonesia terpuruk pada tahun 1997, angka pengangguran tidak kunjung berkurang. Hal ini karena jumlah angkatan kerja yang lulus pada setiap tahunnya tidak bisa terserap habis di tahun tersebut. Untuk mengatasi permasalahan tersebut ada dua metode penyelesaian, yakni dengan meningkatkan kompetensi lulusan dan meningkatkan program pemberdayaan masyarakat. Atas fenomena ini, diharapkan sistem pendidikan di Indonesia dapat dikembangkan untuk meningkatkan angka siap kerja dan mencegah bertambahnya pengangguran. Menjawab permasalahan ini, SMK menjadi salah satu jalan keluarnya dalam menyiapkan sumber daya manusia yang cukup potensial.

Berdasarkan pengamatan dan fenomena yang ada di lapangan, tamatan SMK diperoleh gambaran kurang memiliki sikasp berwirausaha. Siswa SMK. sebenarnya sudah diajarkan tentang pendidikan berwirausaha disekolah, hal ini terlihat belum merupakan dorongan untuk mereka berwirausaha. Sesuai dengan tekad Sekolah Menengah Kejuruan (SMK) untuk menghasilkan lulusan yang berkualitas, diimbangi dengan adanya upaya untuk meningkatkan motivasi belajar siswanya. Sekolah Menegah Kejuruan (SMK) berupaya berperan aktif dalam menyiapkan sumberdaya manusia terdidik yang mampu menghadapi berbagai tantangan kehidupan baik lokal, regional, nasional maupun internasional. Siswa tidak cukup hanya menguasai teori-teori, tetapi juga mau dan mampu menerapkannya dalam kehidupan sosialnya, tidak hanya mampu menerapkan ilmu yang diperoleh di bangku sekolah, tetapi juga mampu memecahkan berbagai persoalan yang dihadapi dalam kehidupan sehari-hari.

Salah satu hal yang sangat berpengaruh dalam hasil belajar siswa adalah pembelajaran Tata Graha. Pembelajaran Tata Graha disekolah terdiri dari tiga komponen yang harus dimiliki oleh siswa yaitu, pengetahuan, sikap dan keterampilan, yang tertuang dalam Kurikulum Tingkat Satuan Pendidikan (KTSP) 2006. Pembelajaran Tata Graha mengarah pada pembentukan sikap yang diharapkan dan diwujudkan pada perilaku sehari- hari. Disamping itu melalui pembelajaran Tata Graha siswa juga dibekali Pengetahuan dan Kemampuan. Dengan demikian diharapkan Pembelajaran Tata Graha tidak menimbulkan kebosanan dan diharapkan dalam pengajaran dapat menyenangkan.

Pelaksanaan Prakerin merupakan bagian dari Pendidikan Sistem Ganda yang merupakan inovasi pada program SMK dimana siswa melakukan praktek kerja (magang) di perusahaan atau industri yang merupakan bagian integral dari proses pendidikan dan pelatihan di SMK. Prakerin dalam rangka pelaksanaan Pendidikan Sistim Ganda (PSG) pada Sekolah Menengah Kejuruan (SMK) didasarkan atas ketentuan yang tertuang dalam Kepmendikbud No. 323/U/1993, tentang Penyelenggaraan PSG pada SMK. Praktek kerja industri merupakan salah satu model penyelenggaraan pendidikan profesional yang memadukan secara sistematis dan sinkronisasi antara pendidikan di sekolah dan penguasaan keahlian atau keterampilan yang diperoleh melalui bekerja langsung di dunia usaha dan dunia industri untuk mencapai suatu tingkat keahlian yang cukup profesional sesuai dengan program keahlian dan yang diharapkan dalam profil kemampuan lulusan SMK (Panduan Prakerin, 2002:5).

Selama siswa melaksanakan Prakerin di DU/DI, pihak sekolah melakukan pengawasan atau monitoring terhadap siswa satu kali sebulan. Kegiatan monitoring bertujuan untuk melihat kemajuan belajar siswa, baik dari segi sikap maupun keterampilan. Kegiatan monitoring 
dilaksanakan oleh guru pembimbing sekolah yang dipercayakan oleh panitia Prakerin sebagai pelaksana monitoring siswa.

Monitoring yang dilaksanakan oleh guru yaitu meliputi, monitoring kompetensi yang dilaksanakan siswa di DU/DI, kemajuan belajar siswa, kehadiran, dan kendala-kendala yang ditemui di lapangan selama pelaksanaan Prakerin. Monitoring kompetensi dilakukan untuk melihat kesesuaian materi atau bimbingan yang diberikan oleh pihak DU/DI terhadap siswa dengan pembelajaran yang diperoleh siswa di sekolah. Sedangkan monitoring kemajuan belajar siswa dilakukan untuk mengetahui kegiatan yang dilakukan siswa di DU/DI dan mengetahui kemampuan yang telah diperoleh siswa selama di DU/DI. Monitoring kehadiran ditujukan bagi sikap siswa, termasuk kedisiplinan, sikap kerja selama Prakerin. Monitoring tentang kendala-kendala ditujukan untuk menerima masukan-masukan dari pihak DU/DI terhadap permasalahan siswa atau kendala yang ditemui pihak DU/DI selama pelaksanaan Prakerin.

Selain pelaksanaan praktik, faktor lain yang mempengaruhi hasil belajar siswa adalah disiplin belajar. Disiplin belajar adalah suatu sikap mental untuk mematuhi aturan tata tertib, dan sekaligus mengendalikan diri, menyesuaikan diri terhadap aturan-aturan yang berasal dari luar sekalipun yang mengekang dan menunjukkan kesadaran akan tanggung jawab terhadap tugas dan kewajiban. Disiplin belajar siswa dapat terjadi secara optimal bila pihak sekolah dan para pendidik (guru) melakukan perbaikan proses belajar mengajar yang menjadikan siswa itu memiliki tingkat yang sama, sama-sama mencari ilmu tanpa ada dinding pemisah yang menghalangi. Sehingga antara guru dan siswa itu akan tercipta saling kerja sama. Dan siswapun menjadi bersemangat dalam belajar karena siswa tidak merasa lebih rendah dari pada guru mereka. Dengan adanya disiplin diri dalam belajar yang tertanam dalam diri setiap siswa, hal ini akan menjadikan mereka lebih aktif dan kreatif dalam belajar. Semakin aktif dan kreatifnya siswa dalam belajar tentu akan berdampak positif terhadap peningkatan hasil belajar siswa.

Selain praktek kerja industridan disiplin belajar, hal lain yang mempengaruhi hasil belajar siswa adalah motivasi berprestasi. Sardiman (2011:73) mengemukakan bahwa motivasi adalah perubahan energi dalam diri seseorang yang ditandai dengan munculnya "feeling" dan didahului dengan tanggapan terhadap adanya tujuan. Motivasi didefinisikan sebagai faktor penentu (determinan) dari perilaku individu dalam wujud kebutuhan (need), dorongan (drivers), dan desakan hati (inpuls), yang bekerja di bawah kesadaran. Jawaban atas pertanyaan mendasar seperti "mengapa individu melakukan suatu aktivitas" akan sampai pada pembahasan tentang motivasi. Motivasi sebagai faktor penentu perilaku bisa diduga dari perilaku yang ditimbulkannya.

Jadi motivasi merupakan daya dorong dalam diri seseorang untuk mengarahkan, melakukan serta menentukan tingkat usaha yang akan dilakukan. Motivasi adalah dorongan dasar yang menggerakkan seseorang bertingkah laku. Dorongan ini berada pada diri seseorang yang menggerakkan untuk melakukan sesuatu yang sesuai dengan dorongan dalam dirinya. Oleh karena itu, perbuatan seseorang yang didasarkan atas motivasi tertentu mengandung tema sesuai dengan motivasi yang mendasarinya.

Peran motivasi dalam kegiatan belajar ditentukan oleh keseriusan dalam mengikuti pelajaran, yang jelas didorong oleh motivasi dari luar dan dari dalam diri siswa itu sendiri. Disini guru sebagai motivator mempunyai peran yang cukup besar dalam meningkatkan motivasi kepada siswa. Pembentukan sikap kewirausahaan dapat terlihat dalam kehidupan sehari- hari seorang siswa. Sikap dan perilaku seseorang cenderung terbentuk oleh faktor-faktor pengalaman pribadi, kebudayaan, orang lain yang dianggap penting, media massa, Institusi atau lembaga pendidikan dan agama, dan faktor emosional.

Menurut undang-undang No 14 Tahun 2005 tentang Undang-undang guru dan dosen dijelaskan bahwa kompetensi guru meliputi kompetensi pedagogik, kompetensi kepribadian, kompetensi sosial, dan kompetensi profesional. Untuk standar kompetensi guru SMK, lebih dijelaskan dalam permendiknas Nomor 16 tahun 2007.Kompetensi pedagogik adalah 
kemampuan mengelola pembelajaran siswa, yaitu kemampuan guru dalam mengelola pembelajaran yang meliputi pemahamna terhadap siswa, perancangan dan pelaksanaan pembelajaran, evaluasi pembelajaran dan pengembangan siswa untuk mengaktualisasikan berbagai potensi yang dimilikinya.

Seorang guru harus memiliki kompetensi pedagogik dan profesional sebagai bekal untuk menjalankan tugasnya, yaitu mendidik dan mencerdaskan siswa. Kompetensi pedagogik mengenai ilmu tentang belajar dan pembelajaran, bagaimana melaksanakan pembelajaran yang baik dan efektif, dan bagaimana membelajarkan siswa agar mereka memahami materi pembelajaran. Sedangkan kompetensi profesional adalah mengenai isi materi pembelajaran atau substansi ilmu yang menaungi materi pembelajaran. Untuk dapat menguasai kompetensi pedagogik dan profesional maka seorang calon pendidik harus menempuh pendidikan khusus untuk menjadi pendidik, yaitu menempuh pendidikan tinggi pada LPTK di Indonesia yang memiliki akreditasi oleh BAN-PT.

Menurut Sunaryo (2009:119) kompetensi pedagogik yang harus dimiliki pendidik antara lain yaitu memiliki kemampuan melaksanakan dan menerapkan (a) structuring (pengaturan waktu yang diperlukan) dengan pembagian yaitu pengantar (introduction) melakukan apersepsi sebanyak $10 \%$ waktu seluruh penampilan, inti dengan waktu $80 \%$ dari keseluruhan; dan penutup atau closure waktunya 10\%; (b) motivating and reinforcing, yaitu kemampuan untuk memupuk memberikan motivasi kepada para siswanya supaya lebih bergairah belajar dengan menonjolkan mengapa mereka harus mempelajari bidang studi tertentu dalam rangka mencapai cita-cita hidupnya; (c) conducting discussing small group activities, proses belajarmengajar dengan metode diskusi; (d) conducting individual activities, kemampuan guru untuk memberikan pada anak didiknya kegiatan perorangan dengan tujuan mengisi kekurangan yang ada pada diri anak baik dalam bidang akademik, emosional, mental dan sebagainya; (e) providing for feedback, guru harus menyediakan umpan balik; (f) presenting informations, guru harus mampu menuangkan buah pikirannya secara tertulis dalam kata-kata yang dapat ditangkap dengan mudah oleh siswa; (g) utilizing inductive or problem solving, prosedur deduktif bertolak dari yang umum ke yang khusus; (h) questioning and responding, komunikasi oleh guru yang dilakukan dengan tanya jawab; dan (i) kemampuan mengoperasikan hardware, yaitu alat-alat penunjang proses pembelajaran seperti LCD, projektor dan sebagainya.

Berdasarkan pemaparan diatas dapat disimpulkan bahwa kompetensi pedagogik yang harus dimiliki oleh seorang pendidik sulit didapat dengan cara mudah dan cepat. Untuk menjadi pendidik yang berkompetensi pedagogik harus menempuh pendidikan yang memenuhi kualifikasi seorang pendidik. Oleh karena itu, sebaiknya pendidik harus benar-benar diseleksi sesuai dengan latar belakang pendidikannya karena pendidik adalah tulang punggung terselenggaranya pendidikan yang bertujuan untuk menghasilkan output yang berkualitas.

Berdasarkan paparan di atas, menunjukkan bahwa praktik kerja industri (prakerin), disiplin belajar, motivasi berprestasi, dan kompetensi pedagogik guru, akan meningkatkan hasil belajar siswa. Namun kenyataan di lapangan, dimana hasil belajar siswa masih rendah, khususnya hasil belajar Tata Graha siswa di Sekolah Menengah Kejuruan (SMK). Apakah tinggi rendahnya hasil belajar di SMK ada kaitannya dengan praktik kerja industri (prakerin), disiplin belajar, motivasi berprestasi, dan kompetensi pedagogik guru, baik secara sendiri-sendiri maupun secara bersama-sama, dan seberapa besar determinasinya masing-masing, maka perlu diadakan penelitian lebih jauh. Penelitian dilakukan di SMK N 2 Singaraja dengan judul Kontribusi Praktik Kerja Industri (Prakerin), Disiplin Belajar, Motivasi Berprestasi, dan Kompetensi Pedagogik Guru Terhadap Hasil Belajar Tata Graha Siswa Kelas XII Jurusan Perhotelan di SMK N 2 Singaraja. Adapun beberapa alasan dilakukan penelitian di sekolah tersebut adalah: (1) masih sedikit penelitian tentang masalah tersebut di Kota Singaraja khususnya di SMK, (2) pemilihan lokasi tersebut berdasarkan keinginan peneliti sebagai salah satu guru di sekolah tersebut untuk ikut berpartisipasi dalam pengembangan lembaga pendidikan SMK khususnya SMK Negeri 2 Singaraja. 


\section{METODE PENELITIAN}

Penelitian ini menggunakan pendekatan "ex-post facto".Karena dalam penelitian ini tidak diadakan perlakuan (treatment atau manipulasi) terhadap sampel penelitian.Sukardi (2007:165) menyatakan bahwa penelitian ex-post facto merupakan penelitian di mana variabel-variabel bebas telah terjadi ketika peneliti mulai dengan pengamatan variabel terikat dalam suatu penelitian. Pada penelitian ini, keterkaitan antarvariabel bebas dengan variabel bebas, maupun antarvariabel bebas dengan variabel terikat sudah terjadi secara alami, dan peneliti dengan setting tersebut ingin melacak kembali jika dimungkinkan apa yang menjadi faktor penyebabnya.

Menurut Agung $(2014 ; 69)$ menyatakan populasi adalah keseluruhan objek dalam suatu penelitian. Sedangkan menurut Sugiyono (2017:61) populasi adalah wilayah generalisasi yang terdiri atas objek dan subjek yang mempunyai kualitas dan karakteristik tertentu yang ditetapkan oleh peneliti untuk dipelajari dan kemudian ditarik kesimpulannya.

Populasi dalam penelitian ini adalah seluruh siswa kelas XII Jurusan Perhotelan di SMK N 2 Singaraja.Jumlah siswa kelas XII Jurusan Perhotelan di SMK N 2 Singarajaadalah sebanyak 158 orang. Menurut Agung $(2016 ; 8)$ menyatakan bahwa sampel merupakan bagian dari populasi yang secara langsung dikenai penelitian. Sedangkan menurut Sugiyono $(2016 ; 120)$ menyatakan bahwa sampel adalah bagian dari jumlah dan karakteristik yang dimiliki populasi tersebut. Berdasarkan tabel Morgan, apabila jumlah populasi sebanyak 158 orang, maka sampel yang bisa diambil adalah 113 orang. Sehingga sampel dalam penelitian ini berjumlah 113 orang.

Variabel bebas dalam penelitian ini adalah praktik kerja industri(X1), disiplin belajar(X2), motivasi berprestasi(X3) dankompetensi pedagogik guru(X4).Adapun variabel terikatnya adalah hasil belajar Tata Graha (Y).Hubungan antara variabel bebas dan variabel terikat secara sederhana dapat digambarkan konstelasi permasalahan.

Pengumpulan data adalah suatu proses pengadaan data primer untuk keperluan penelitian yang digunakan untuk menguji hipotesis yang telah dirumuskan. Untuk memperoleh data mengenai variabel yang diteliti, dalam penelitian ini data dikumpulkan dengan kuesioner dan lembar observasi mengenai data tentang praktik kerja industri (prakerin), disiplin belajar, motivasi berprestasi, kompetensi pedagogik guru, dan hasil belajar Tata Graha. Untuk memperoleh data tersebut digunakan empat buah instrument, yaitu: 1) lembar observasi praktik kerja industri (prakerin), 2) kuesioner disiplin belajar, dan 3) kuesioner motivasi berprestasi, dan 4) kuesionerkompetensi pedagogik guru.

Alat pengumpul data harus memenuhi persyaratan yaitu syarat validitas dan reliabilitas dalam mengungkap apa yang hendak diukur. Ada dua persyaratan yang hendak digunakan dalam pengumpulan data penelitian yaitu validitas dan reliabilitas (Hamzah, 2007:63). Validitas instrumen dalam penelitian ini meliputi dua segi yaitu validitas isi dan validitas butir. Validitas isi dibantu oleh dua orang ahli/ expert, kemudian dianalisis dengan teknik Gregory.

Sebelum instrumen digunakan, maka perlu diuji dahulu validitas dari masing-masing pernyataan yang ada sebagai alat pengambilan data. Dengan demikian terlebih dahulu diadakan uji coba terhadap kuisioner kemudian hasil uji coba ini dianalisis. Data yang telah diperoleh dari penelitian dideskripsikan menurut masing-masing variable. Oleh tujuannya seperti itu, maka akan dicari harga rerata (M), standar deviasi (SD), modus (Mo), dan median (Me) setiap variabel yang diteliti.

Setelah data dideskripsikan, maka analisis dilanjutkan dengan menggunakan teknik regresi sederhana, regresi ganda, dan korelasi varsial.Persyaratan yang berkaitan dengan teknik analisis data tersebut harus dibuktikan secara statistik.

Setelah seluruh uji prasyarat terpenuhi, maka dilanjutkan dengan uji hipotesis. Untuk menguji hipotesis pertama, kedua, ketiga dan keempat dalam penelitian ini digunakan teknik analisis korelasi sederhana (korelasi product moment pearson). Sedangkan untuk menguji hipotesis ke empat, digunakan teknik analisis korelasi ganda, regresi ganda, dan korelasi 
parsial. Untuk menganalisis uji hipotesis dalam penelitian ini digunakan program SPSS-17.00 for windows.

\section{HASIL PENELITIAN DAN PEMBAHASAN}

\section{Hubungan Praktik Kerja Industri (Prakerin) dengan Hasil Belajar Tata Graha Siswa}

Berdasarkan analisis data yang telah dilakukan, Secara normatif ditemukan bahwa prakerin berada pada kategori sangat baik. Selain itu, hasil analisis juga menunjukkan bahwa terdapat korelasi yang signifikan antara prakerin dengan hasil belajar Tata Graha siswa kelas XII Jurusan Perhotelan di SMK Negeri 2 Singaraja melalui persamaan garis regresi $\hat{y}=21,147$ $+0,622$.X1dengan Freg $=64,165(p<0,05)$. Sedangkan korelasi yang signifikan terjadi antara prakerin dengan hasil belajar Tata Graha sebesar 0,605 dengan $p<0,05$ dan variabel prakerin dapat menjelaskan hasil belajar Tata Graha siswa kelas XII Jurusan Perhotelan di SMK Negeri 2 Singaraja sebesar $36,6 \%$. Temuan ini mengindikasikan bahwa prakerin mempunyai peranan penting dalam meningkatkan hasil belajar Tata Graha siswa kelas XII Jurusan Perhotelan di SMK Negeri 2 Singaraja. Sumbangan efektif (SE) variabel prakerin terhadap hasil belajar Tata Graha siswa kelas XII Jurusan Perhotelan di SMK Negeri 2 Singaraja adalah sebesar 13,18\%.

Temuan dalam penelitian ini sejalan dengan temuan penelitian yang dilakukan oleh Faozi (2013) meneliti tentang pengaruh praktek kerja industri (Prakerin) terhadap motivasi belajar siswa kelas XI Teknik Otomotif Kendaraan Ringan. yang menyimpulkan bahwa apabila nilai Prakerin tinggi maka Motivasi Belajar siswa juga akan tinggi, begitu juga sebaliknya apabila nilai Prakerin rendah maka Motivasi Belajar siswa akan rendah juga. Berdasarkan hasil uji regresi variabel Praktek Kerja Industri menunjukkan ada pengaruh positif variabel Praktek Kerja Industri terhadap Motivasi Belajar, dengan nilai koefisien regresi sebesar 0,200. Hasil tersebut mengidentifikasikan semakin baik Prakerin, maka Motivasi Belajar akan semakin meningkat.

Pelaksanaan Prakerin merupakan bagian dari Pendidikan Sistem Ganda yang merupakan inovasi pada program SMK dimana siswa melakukan praktek kerja (magang) di perusahaan atau industri yang merupakan bagian integral dari proses pendidikan dan pelatihan di SMK. Prakerin dalam rangka pelaksanaan Pendidikan Sistim Ganda (PSG) pada Sekolah Menengah Kejuruan (SMK) didasarkan atas ketentuan yang tertuang dalam Kepmendikbud No. 323/U/1993, tentang Penyelenggaraan PSG pada SMK. Praktek kerja industri merupakan salah satu model penyelenggaraan pendidikan profesional yang memadukan secara sistematis dan sinkronisasi antara pendidikan di sekolah dan penguasaan keahlian atau keterampilan yang diperoleh melalui bekerja langsung di dunia kerja dan dunia industri untuk mencapai suatu tingkat keahlian yang cukup profesional sesuai dengan program keahlian dan yang diharapkan dalam profil kemampuan lulusan SMK.

Selama siswa melaksanakan Prakerin di DU/DI, pihak sekolah melakukan pengawasan atau monitoring terhadap siswa satu kali sebulan. Kegiatan monitoring bertujuan untuk melihat kemajuan belajar siswa, baik dari segi sikap maupun keterampilan. Kegiatan monitoring dilaksanakan oleh guru pembimbing sekolah yang dipercayakan oleh panitia Prakerin sebagai pelaksana monitoring siswa. Berdasarkan pemaparan di atas, dapat disimpulkan bahwa pelaksanaan Prakerin memiliki hubungan yang sangat kuat dengan hasil belajar Tata Graha siswa.

Berdasarkan pemaparan di atas, maka dapat disimpulkan bahwa prakerin memberikan kontribusi yang signifikan terhadap hasil belajar Tata Graha pada siswa kelas XII Jurusan Perhotelan di SMK Negeri 2 Singaraja.

\section{Hubungan Disiplin Belajardengan Hasil Belajar Tata Graha Siswa}

Berdasarkan analisis data yang telah dilakukan, secara normatif ditemukan bahwa disiplin belajar berada pada kategori sangat baik. Selain itu, hasil analisis juga menunjukkan bahwa terdapat korelasi yang signifikan antara disiplin belajar dengan siswa kelas XII Jurusan Perhotelan di SMK Negeri 2 Singaraja melalui persamaan garis regresi $\hat{y}=0,343+0,327 X 2$ dengan Freg $=129,479(p<0,05)$. Sedangkan korelasi yang signifikan terjadi antara disiplin 
belajar dengan hasil belajar Tata Graha sebesar 0,734 dengan $p<0,05$ dan variabel disiplin belajar dapat menjelaskan siswa kelas XII Jurusan Perhotelan di SMK Negeri 2 Singaraja sebesar 53,8\%. Temuan ini mengindikasikan bahwa disiplin belajar mempunyai peranan penting dalam meningkatkan hasil belajar Tata Graha siswa kelas XII Jurusan Perhotelan di SMK Negeri 2 Singaraja. Sumbangan efektif (SE) variabel prakerin kepala sekolah terhadap hasil belajar Tata Graha siswa kelas XII Jurusan Perhotelan di SMK Negeri 2 Singaraja adalah sebesar $20,44 \%$.

Temuan dalam penelitian ini sejalan dengan temuan penelitian yang dilakukan oleh Widiantara (2013) meneliti tentang determinasi kualitas pengelolaan pembelajaran, disiplin belajar, motivasi berprestasi terhadap hasil belajar bahasa indonesia kelas X SMK PGRI 5 Denpasar. Dalam penelitiannya dinyatakan bahwa (1). Kualitas Pengelolaan Pembelajaran, Disiplin Belajar dan Motivasi Berprestasi masing-masing memiliki determinasi yang signifikan terhadap Hasil Belajar Bahasa Indonesia, dan (2) secara bersama-sama memiliki determinasi yang signifikan terhadap Hasil Belajar Bahasa Indonesia.

Disiplin belajar adalah suatu sikap mental untuk mematuhi aturan tata tertib, dan sekaligus mengendalikan diri, menyesuaikan diri terhadap aturan-aturan yang berasal dari luar sekalipun yang mengekang dan menunjukkan kesadaran akan tanggung jawab terhadap tugas dan kewajiban. Disiplin belajar siswa dapat terjadi secara optimal bila pihak sekolah dan para pendidik (guru) melakukan perbaikan proses belajar mengajar yang menjadikan siswa itu memiliki tingkat yang sama, sama-sama mencari ilmu ilmu tanpa ada dinding pemisah yang menghalangi. Sehingga antara guru dan siswa itu akan tercipta saling kerja sama. Dan siswapun menjadi bersemangat dalam belajar karena siswa tidak merasa lebih rendah dari pada guru mereka. Dengan adanya disiplin diri dalam belajar yang tertanam dalam diri setiap siswa, hal ini akan menjadikan mereka lebih aktif dan kreatif dalam belajar.

Semakin disiplin siswa dalam belajar tentu akan berdampak positif terhadap peningkatan hasil belajar Tata Graha siswa. Sehingga dapat disimpulkan bahwa disiplin belajar memiliki hubungan yang sangat erat dengan hasil belajar Tata Graha siswa.

Berdasarkan pemaparan di atas, maka dapat disimpulkan bahwa disiplin belajar memberikan kontribusi yang signifikan terhadap hasil belajar Tata Graha pada siswa kelas XII Jurusan Perhotelan di SMK Negeri 2 Singaraja.

\section{Hubungan Motivasi Berprestasidengan Hasil Belajar Tata Graha Siswa}

Berdasarkan analisis data yang telah dilakukan, secara normatif ditemukan bahwa motivasi berprestasi berada pada kategori sangat baik. Selain itu, hasil analisis juga menunjukkan bahwa terdapat korelasi yang signifikan antara motivasi berprestasi dengan hasil belajar Tata Graha siswa kelas XII Jurusan Perhotelan di SMK Negeri 2 Singaraja melalui persamaan garis regresi $\hat{y}=31,560+0,305 \times 3$ dengan Freg $=34,315(p<0,05)$. Sedangkan korelasi yang signifikan terjadi antara motivasi berprestasi dengan hasil belajar Tata Graha sebesar 0,486 dengan $p<0,05$ dan variabel motivasi berprestasi dapat menjelaskan hasil belajar Tata Graha siswa kelas XII Jurusan Perhotelan di SMK Negeri 2 Singaraja sebesar 23,6\%. Temuan ini mengindikasikan bahwa motivasi berprestasi mempunyai peranan penting dalam meningkatkan hasil belajar Tata Graha siswa kelas XII Jurusan Perhotelan di SMK Negeri 2 Singaraja. Sumbangan efektif (SE) variabel motivasi berprestasi terhadap hasil belajar Tata Graha siswa kelas XII Jurusan Perhotelan di SMK Negeri 2 Singaraja adalah sebesar $7,89 \%$.

Hasil penelitian ini sejalan dengan hasil penelitian yang dilakukan oleh Juliarta (2013) meneliti tentang determinasi motivasi berprestasi, kebiasaan belajar, dan kualitas pengelolaan pembelajaran guru terhadap prestasi belajar praktik (studi persepsi siswa seni rupa di SMKN 1 Sukawati). Dalam penelitianya dinyatakan bahwa (1) ditemukan hubungan positif dan signifikan antara motivasi berprestasi (X1) dengan prestasi belajar praktik seni rupa (Y), dengan kontribusi sebesar 5,7\%; (2) ditemukan hubungan secara signifikan antara kebiasaan belajar (X2) dengan prestasi belajar praktik seni rupa (Y), dengan kontribusi sebesar 6,2\%; (3) ) 
ditemukan hubungan positif dan signifikan antara motivasi berprestasi (X3) dengan prestasi belajar praktik seni rupa (Y), dengan kontribusi sebesar 10,1\%; (4) ) ditemukan hubungan positif dan signifikan antara motivasi berprestasi, kebiasaan belajar, kualitas pengelolaan pembelajaran guru secara bersama-sama terhadap prestasi belajar praktik seni rupa, dengan kontribusi sebesar 23,9\%.

Motivasi didefinisikan sebagai faktor penentu (determinan) dari perilaku individu dalam wujud kebutuhan (need), dorongan (drivers), dan desakan hati (inpuls), yang bekerja di bawah kesadaran. Jawaban atas pertanyaan mendasar seperti "mengapa individu melakukan suatu aktivitas" akan sampai pada pembahasan tentang motivasi. Motivasi sebagai faktor penentu perilaku bisa diduga dari perilaku yang ditimbulkannya.

Jadi motivasi merupakan daya dorong dalam diri seseorang untuk mengarahkan, melakukan serta menentukan tingkat usaha yang akan dilakukan. Motivasi adalah dorongan dasar yang menggerakkan seseorang bertingkah laku. Dorongan ini berada pada diri seseorang yang menggerakkan untuk melakukan sesuatu yang sesuai dengan dorongan dalam dirinya. Oleh karena itu, perbuatan seseorang yang didasarkan atas motivasi tertentu mengandung tema sesuai dengan motivasi yang mendasarinya.

Dalam pembelajaran Tata Graha, seseorang yang memiliki motivasi berprestasi tinggi cenderung akan selalu berusaha untuk menguasai materi secara maksimal, sehingga hasil belajar Tata Graha pun dapat tercapai secara maksimal pula. Maka dari itu, dapat disimpulkan bahwa motivasi berprestasi memiliki hubungan yang kuat dengan hasil belajar Tata Graha siswa.

Berdasarkan pemaparan di atas, maka dapat disimpulkan bahwa motivasi berprestasi memberikan kontribusi yang signifikan terhadap hasil belajar Tata Graha pada siswa kelas XII Jurusan Perhotelan di SMK Negeri 2 Singaraja.

\section{Hubungan Kompetensi Pedagogik Guru dengan Hasil Belajar Tata Graha Siswa}

Berdasarkan analisis data yang telah dilakukan, secara normatif ditemukan bahwa kompetensi pedagogik berada pada kategori sangat baik. Selain itu, hasil analisis juga menunjukkan bahwa terdapat korelasi yang signifikan antara kompetensi pedagogik dengan hasil belajar Tata Graha siswa kelas XII Jurusan Perhotelan di SMK Negeri 2 Singaraja melalui persamaan garis regresi $\hat{y}=19,388+0,342 X 4$ dengan Freg $=128,657(p<0,05)$. Sedangkan korelasi yang signifikan terjadi antara kompetensi pedagogik dengan hasil belajar Tata Graha sebesar 0,733 dengan $p<0,05$ dan variabel motivasi berprestasi dapat menjelaskan hasil belajar Tata Graha siswa kelas XII Jurusan Perhotelan di SMK Negeri 2 Singaraja sebesar $53,7 \%$. Temuan ini mengindikasikan bahwa kompetensi pedagogik mempunyai peranan penting dalam meningkatkan hasil belajar Tata Graha siswa kelas XII Jurusan Perhotelan di SMK Negeri 2 Singaraja. Sumbangan efektif (SE) variabel kompetensi pedagogik terhadap hasil belajar Tata Graha siswa kelas XII Jurusan Perhotelan di SMK Negeri 2 Singaraja adalah sebesar $21,66 \%$.

Hasil penelitian ini sejalan dengan hasil penelitian yang dilakukan oleh Costa, dkk (2014) yang berjudul Pedagogical Interaction and Learning Performance as Determinants of Academic Achievement. The results obtained through the structural model show that perceived teacher competencies influence student-student interactions and learning performance positively and significantly; student-student interactions positively and significantly influence the learning performance which, in turn, influences positively and significantly students' academic achievement. The established model provides insights for a better understanding of the importance of communication, in the context of the classroom, and of the students' learning involvement in the academic activities, towards the promotion of school success.

Kompetensi merupakan penguasaan terhadap suatu tugas, keterampilan, sikap, dan apresiasi yang diperlukan untuk menunjang keberhasilan. Sementara itu, menurut Kepmendiknas 047/U/2002 adalah seperangkat tindakan cerdas, penuh tanggung jawab yang dimiliki seseorang sebagai syarat untuk dianggap mampu oleh masyarakat dalam 
melaksanakan tugas-tugas dibidang pekerjan tertentu. Lebih lanjut Gordon dan Mulyasa, (2005) merinci beberapa aspek yang ada dalam konsep kompetensi yakni:(1)pengetahuan (Knowledge), (2) pemahaman (Understanding), (3) kemampuan (Skill), (4) nilai, (5) sikap, dan (6) minat (Interest).

Jika dilihat dari segi istilah, pedagogik sendiri berasal dari Yunani Kuno, yaitu paedos (anak) dan agogos (mengantar, membimbing, memimpin). Dari dua istilah di atas timbul istilah baru yaitu paedagogos dan pedagog. Keduanya memiliki pngertian yang hampir serupa, yaitu sebutan untuk pelayan pada zaman Yunani Kuno yang mengantarkan atau membimbing anak dari rumah ke sekolah setelah sampai di sekolah anak dilepas, dalam pengertian pedagog intinya adalah mengantarkan anak menuju pada kedewasaan. Istilah lainya yaitu Paedagogik yang berarti pergaulan dengan anak, Pedagogi yang merupakan praktek pendidikan anak kemudian muncullah istilah "pedagogik yang berarti ilmu mendidik anak".

Pedagogik juga merupakan suatu ilmu, sehingga orang menyebutnya ilmu pedagogik. IImu pedagogik adalah ilmu yang membicarakan masalah atau persoalan-persoalan dalam pendidikan dan kegiatan-kegiatan mendidik, antara lain tujuan pendidikan, alat pendidikan, cara melaksanakan pendidikan, anak didik, pendidik dan sebagainya. Pedagogik termasuk ilmu yang sifatnya teoritis dan praktis. Oleh karena itu pedagogik banyak berhubungan dengan ilmuilmu lain seperti: ilmu sosial, ilmu psikologi, psikologi belajar, metodelogi pengajaran, sosiologi, filsafat dan lainnya.

Kompetensi pedagogik adalah kemampuan mengelola pembelajaran siswa, yaitu kemampuan guru dalam mengelola pembelajaran yang meliputi pemahaman terhadap siswa, perancangan dan pelaksanaan pembelajaran, evaluasi pembelajaran dan pengembangan siswa untuk mengaktualisasikan berbagai potensi yang dimilikinya.

Seorang guru harus memiliki kompetensi pedagogik dan profesional sebagai bekal untuk menjalankan tugasnya, yaitu mendidik dan mencerdaskan siswa. Kompetensi pedagogik mengenai ilmu tentang belajar dan pembelajaran, bagaimana melaksanakan pembelajaran yang baik dan efektif, dan bagaimana membelajarkan siswa agar mereka memahami materi pembelajaran. Sedangkan kompetensi profesional adalah mengenai isi materi pembelajaran atau substansi ilmu yang menaungi materi pembelajaran. Berdasarkan pemaparan di atas, dapat disimpulkan bahwa kompetensi pedagogik yang dimiliki oleh guru memiliki hubungan yang sangat kuat dengan hasil belajar Tata Graha siswa.

Berdasarkan pemaparan di atas, maka dapat disimpulkan bahwa guru yang memiliki kompetensi pedagogik yang baik, tentunya akan mampu memberikan pembelajaran yang baik kepada siswa, sehingga kemampuan guru dalam mengelola proses pembelajaran tidak perlu diragukan lagi. Dengan kata lain, kompetensi pedagogik memberikan kontribusi terhadap kemampuan guru dalam mengelola proses pembelajaran.

\section{Hubungan Praktik Kerja Industri (Prakerin), Disiplin Belajar, Motivasi Berprestasi, dan Kompetensi Pedagogik Guru Terhadap Hasil Belajar Tata Graha Siswa}

Berdasarkan analisis yang telah dilakukan, ditemukan bahwa terdapat korelasi yang signifikan secara bersama-sama antara prakerin kepala sekolah, disiplin belajar, motivasi berprestasi, dan kompetensi pedagogik terhadap hasil belajar Tata Graha melalui persamaan garis regresi $\hat{y}=29,764+0,224 X 1+0,124 X 2+0,102 X 3+0,138 X 4$ dengan Freg $=46,189$ $(p<0,05)$. Ini berarti terdapat hubungan secara bersama-sama antara prakerin, disiplin belajar, motivasi berprestasi, dan kompetensi pedagogik terhadap hasil belajar Tata Graha siswa kelas XII Jurusan Perhotelan di SMK Negeri 2 Singaraja. Hal ini mengindikasikan bahwa makin baik prakerin, disiplin belajar, motivasi berprestasi, dan kompetensi pedagogik makin baik pula hasil belajar Tata Graha tersebut.

Korelasi murni antara prakerin, disiplin belajar, motivasi berprestasi, dan kompetensi pedagogik dengan hasil belajar Tata Graha siswa kelas XII Jurusan Perhotelan di SMK Negeri 2 Singaraja yang diperoleh melalui analisis korelasi parsial jenjang kedua. Hasil yang diperoleh adalah: pertama, terdapat korelasi yang signifikan antara variabel prakerin terhadap hasil 
belajar Tata Graha dengan dikendalikan oleh variabel disiplin belajar, motivasi berprestasi, dan kompetensi pedagogik $\left(r_{1 y-234}=0,605\right)$ dengan $\left.p<0,05\right)$. Ini menunjukkan bahwa prakerin memberikan kontribusi yang signifikan terhadap hasil belajar Tata Graha siswa kelas XII Jurusan Perhotelan di SMK Negeri 2 Singaraja, sehingga dapat dijadikan prediktor kecenderungan tingkat hasil belajar Tata Graha siswa kelas XII Jurusan Perhotelan di SMK Negeri 2 Singaraja.

Kedua, terdapat korelasi yang signifikan disiplin belajar terhadap hasil belajar Tata Graha dengan dikendalikan oleh variabel prakerin, motivasi berprestasi, dan kompetensi pedagogik $\left(r_{2 y-134}=0,734\right.$ dengan $\left.p>0,05\right)$. Ini menunjukkan bahwa disiplin belajar memberikan kontribusi terhadap hasil belajar Tata Graha siswa kelas XII Jurusan Perhotelan di SMK Negeri 2 Singaraja, sehingga dapat dijadikan prediktor kecenderungan tingkat hasil belajar Tata Graha siswa kelas XII Jurusan Perhotelan di SMK Negeri 2 Singaraja.

Ketiga, terdapat korelasi yang signifikan antara motivasi berprestasi terhadap hasil belajar Tata Graha dengan dikendalikan oleh variabel prakerin, disiplin belajar, dan kompetensi pedagogik $\quad\left(r_{3 y-124}=0,486\right.$ dengan $\left.p>0,05\right)$. Ini menunjukkan bahwa motivasi berprestasi memberikan kontribusi terhadap hasil belajar Tata Graha siswa kelas XII Jurusan Perhotelan di SMK Negeri 2 Singaraja, sehingga dapat dijadikan prediktor kecenderungan tingkat hasil belajar Tata Graha siswa kelas XII Jurusan Perhotelan di SMK Negeri 2 Singaraja.

Keempat, terdapat korelasi yang signifikan antara kompetensi pedagogik terhadap hasil belajar Tata Graha dengan dikendalikan oleh variabel prakerin, disiplin belajar dan motivasi berprestasi $\left(r_{4 y-123}=0,733\right.$ dengan $\left.p>0,05\right)$. Ini menunjukkan bahwa kompetensi pedagogik memberikan kontribusi terhadap hasil belajar Tata Graha siswa kelas XII Jurusan Perhotelan di SMK Negeri 2 Singaraja, sehingga dapat dijadikan prediktor kecenderungan tingkat hasil belajar Tata Graha siswa kelas XII Jurusan Perhotelan di SMK Negeri 2 Singaraja.

Kekuatan hubungan keempat variabel bebas dengan hasil belajar Tata Graha siswa kelas XII Jurusan Perhotelan di SMK Negeri 2 Singaraja secara berurutan adalah: prakerin, disiplin belajar, motivasi berprestasi, dan kompetensi pedagogik mempunyai kontribusi terhadap hasil belajar Tata Graha.

\section{PENUTUP}

Berdasarkan hasil penelitian dan pembahasan yang telah dilakukan, maka dapat ditarik kesimpulan sebagai berikut.

Pertama, terdapat kontribusi yang signifikan antara prakerin terhadap hasil belajar Tata Graha pada siswa kelas XII Jurusan Perhotelan di SMK Negeri 2 Singaraja dengan koefisien korelasi sebesar 0,605, korelasi parsial sebesar 0,272 dan sumbangan efektifnya sebesar $13,18 \%$.

Kedua, terdapat kontribusi yang signifikan antara disiplin belajar terhadap hasil belajar Tata Graha pada siswa kelas XII Jurusan Perhotelan di SMK Negeri 2 Singaraja. dengan koefisien korelasi sebesar 0,734 , korelasi parsial sebesar 0,225 dan sumbangan efektifnya sebesar $20,44 \%$.

Ketiga, ada kontriubusi yang signifikan antara motivasi berprestasi terhadap hasil belajar Tata Graha pada siswa kelas XII Jurusan Perhotelan di SMK Negeri 2 Singaraja dengan koefisien korelasi sebesar 0,486, korelasi parsial sebesar 0,229 dan sumbangan efektifnya sebesar $7,89 \%$.

Keempat, ada kontriubusi yang signifikan antara kompetensi pedagogik terhadap hasil belajar Tata Graha pada siswa kelas XII Jurusan Perhotelan di SMK Negeri 2 Singaraja dengan koefisien korelasi sebesar 0,733, korelasi parsial sebesar 0,241 dan sumbangan efektifnya sebesar $21,66 \%$.

Kelima, secara bersama-sama, terdapat kontribusi yang signifikan antara prakerin, disiplin belajar, motivasi berprestasi, dan kompetensi pedagogik terhadap hasil belajar Tata Graha pada siswa kelas XII Jurusan Perhotelan di SMK Negeri 2 Singaraja dengan koefisien korelasi ganda sebesar 0,794 dan kontribusinya sebesar 63,10\% terhadap hasil belajar Tata Graha 
siswa kelas XII Jurusan Perhotelan di SMK Negeri 2 Singaraja.

Berdasarkan hasil dan kesimpulan dari penelitian ini, dapat diajukan beberapa saran sebagai berikut.

Siswa seharusnya dapat meningkatkan hasil prakerin, motivasi berprestasi dan disiplin belajarnya agar dapat meningkatkan hasil belajar yang mereka peroleh.Guru hendaknya mampu untuk meningkatkan kompetensi pedagogik sehingga hasil belajar Tata Graha dapat ditingkatkan. Hal ini bertujuan agar proses pembelajaran yang ada di sekolah dapat berjalan secara optimal, sehingga tujuan pembelajaran yang ingin dicapai dapat tercapai secara maksimal.Kepala sekolah hendaknya mampu untuk meningkatkan kemampuan manajerialnya, sehingga kepala sekolah akan menjadi panutan bagi guru dan staf yang ada di sekolah. Selain itu kepala sekolah hendaknya juga mampu untuk mengayomi seluruh bawahannya sehingga kegiatan-kegiatan di sekolah dapat berjalan dengan optimal.Pengawas hendaknya mampu mensupervisi dan meningkatkan motivasi seluruh stake holder sekolah yang diampunya, sehingga prestasi sekolah yang diampunya tersebut dapat ditingkatkan.Peneliti lain diharapkan mampu mengembangkan variabel lain dalam usaha meningkatkan hasil belajar Tata Graha, sehingga dapat memberikan kontribusi pengetahuan bagi pendidikan di Indonesia.

\section{DAFTAR RUJUKAN}

Agung, Anak Agung Gede. 2014. Metodologi Penelitian Pendidikan. Malang: Aditya Media Publishing.

Agung, Anak Agung Gede. 2016. Statistika Dasar untuk Pendidikan. Yogyakarta; Deepublish.

Arikunto, Suharsimi. 1995.Manajemen Penelitian.Jakarta: Rineka Cipta.

Arikunto, Suharsimi. 1997. Prosedur Penelitian Suatu Pendekatan Praktek.Jakarta: Rineka Cipta.

Costa, dkk. 2014. Pedagogical Interaction and Learning Performance as Determinants of Academic Achievement. International Journal ICEEPSY 2015 halaman 874-881.

Faozi, Amin. 2013. Pengaruh Praktek Kerja Industri (Prakerin) Terhadap Motivasi Belajar Siswa Kelas XI Teknik Otomotif Kendaraan Ringan.e Journal IKIP Veteran Semarang.Gardan. Vol. 3 No. 2.

Hamzah, B. Uno. 2007. Teori Motivasi dan Pengukurannya. Jakarta:Bumi Aksana.

Juliantara, I Putu Bambang. 2013. Determinasi Motivasi Berprestasi, Kebiasaan Belajar, dan Kualitas Pengelolaan Pembelajaran Guru Terhadap Prestasi Belajar Praktik (Studi Persepsi Siswa Seni Rupa Di SMKN 1 Sukawati). E-Journal Program Pascasarjana Universitas Pendidikan Ganesha. Program Studi Administrasi Pendidikan. Volume 4.

Keputusan Menteri Pendidikan dan Kebudayaan No. 323/U/1997 tentang Penyelenggaraan Pendidikan Sistem Ganda pada Sekolah Menengah Kejuruan.

Puger, I Gusti Ngurah. 2004. Belajar Kooperatif. Diktat Perkuliahan Mahasiswa Unipas.

Sardiman, A.M. 2011. Interaksi dan Motivasi Belajar Mengajar. Jakarta:Rajawali Press.

Sugiyono. 2016. Metode Penelitian Kuantitatif, Kualitatif dan R\&D. Bandung:PT Alfabet.

Sugiyono. 2017. Statistika untuk Penelitian. Bandung: Alfabeta. 
JAPI, Vol. 10 No. 1, Bulan April Tahun 2019

ISSN: 2613-9561

Sukardi, 2007. Metodologi Penelitian Pendidikan. Jakarta: PT.Bumi Aksara

Sunaryo. 2009. Manajemen Risiko Finansial. Jakarta: Salemba Empat.

Undang-undang Republik Indonesia No. 14 Tahun 2005. Tentang Guru dan Dosen

Widiantara, Made. 2013. Determinasi Kualitas Pengelolaan Pembelajaran, Disiplin Belajar, Motivasi Berprestasi Terhadap Hasil Belajar Bahasa Indonesia Kelas X SMK PGRI 5 Denpasar. e-Journal Program Pascasarjana Universitas Pendidikan Ganesha. Program Sudi Administrasi Pendidikan. Volume 4 No. 1. 